\title{
USING FOSSILS TO IDENTIFY ALLOCHTHONOUS OCEANIC ISLANDS IN THE ANCIENT GEOLOGIC RECORD
}

\author{
SOJA*, Constance M., Bunting Institute of Radcliffe College, 34 Concord Avenue, \\ Cambridge, MA 02138, U.S.A.
}

Silurian organisms preserved in southeastern Alaska (Alexander terrane) inhabited marine environments within an island-arc complex during a phase of waning volcanism and are fossilized in a diversity of shallow-marine platform and deep-water deposits. These fossils exhibit a distinctive suite of characteristics and share fundamental similarities with biotas of Paleozoic-Mesozoic age that are preserved in other accreted island terranes of North America. These special attributes reflect the colonization, evolution, and diversification of marine organisms adjacent to subconical/conical volcanic edifices characterized by relatively high rates of subsidence, steep submarine slopes, tectonic instability, and biogeographic isolation. Recognition of these diagnostic features enables many ancient island faunas to be distinguished from those that lived on the craton and enhances differentiation of island biotas from pelagic assemblages that accumulated as oozes in deep ocean basins.

Although island faunas exhibit a high degree of variability in taxonomic diversity, levels of endemism, and provincial affinities, many share a significant number of similarities. Several of these shared attributes reflect organismal evolution in biogeographic isolation at island sites separated from continental and other source regions by considerable geographic distances or at locations unfavorably situated with respect to oceanic currents transporting teleplanic larvae. Comparison of Silurian island-arc faunas from Alaska with coeval assemblages from different tectonic settings and with modern volcanic islands shows that oceanic island biotas commonly are characterized by: (1) initially impoverished, normal marine faunas of low diversity and abundance that are preserved in exceptionally thick platform sequences; (2) sequential development of organic structures from fringing to barrier reefs on the outer shelf during thermal subsidence and lateral expansion of the carbonate platform; (3) restricted faunas devoid of normal marine shelly benthos and tolerant of quiet-water conditions, muddy substrates, and fluctuations in salinity, temperature, and oxygen concentrations in back-reef lagoons; (4) extensive taphonomic redistribution of organisms along bathymetric gradients and downslope preservation in debris flows, slumps, and turbidites of mixed fossil assemblages derived from shelf and shelf-margin habitats; (5) rapid lateral and vertical changes in biofacies, reflecting complex depositional systems in fault-block basins; (6) insular biotas with relatively high levels of endemism; (7) complex paleobiogeographic affinities expressed in assemblages that comprise mixtures of taxa from different faunal regions; and (8) relict biotas that may represent the protracted survival of some organisms in island refugia.

Because many accreted islands are poorly preserved and highly deformed, recognizing these distinctive features in oceanic island faunas enhances identification of allochthonous volcanic arcs, seamounts, atolls, and hot-spot islands in the ancient geologic record. Using fossils to identify islands in accreted terranes is especially important when island origins of strata are suspected but difficult to prove because calc-alkaline volcano-plutonic rocks or derivative volcanogenic and quartz-poor siliciclastic deposits are absent or not exposed. Hence, relying on fossils to recognize oceanic islands that survived destructive tectonic processes offers an expanded list of geologic criteria to aid in reconstructing plate boundaries marking ancient zones of convergence and to use in unraveling the tectonic history of ocean basins recorded in suspect terranes. 